\title{
PERUBAHAN POLA HUBUNGAN SOSIAL (KELUARGA, KOMUNITAS DAN PERKUMPULAN) PADA MASYARAKAT KAMPUNG GODEGAN RT 10 TAMANTIRTA KASIHAN BANTUL
}

\author{
Supriyadi \\ Program Studi Pendidikan Pancasila dan Kewarganegaraan \\ Universitas Ahmad Dahlan \\ Email: supriyadi902@yahoo.co.id
}

\begin{abstract}
ABSTRAK
Penelitian ini adalah penelitian eksploratif yang bertujuan memecahkan problem diskriptif Diskripsi yang dimaksud adalah mengenai proses-proses perubahan dalam hubungan sosial kekeluargaan, komunitas, dan perkumpulan.

Pengumpulan data dilakukan dengan metode partisipan, sedangkan analisis dilakukan dengan menghubung-hubungkan fakta satu dengan lainnya yang diperoleh untuk mendapatkan gambaran umum proses perubahan dalam hubungan social tersebut di atas. Kerangka pemikiran dalam analisis didasarkan pada teori-teori modernisasi, terutama teori diferensiasi struktural dan diffusi sosial.

Hasil penelitian menunjukkan adanya proses perubahan (diferensiasi struktural dan diffusi sosial) pada peran dan gaya hidup dalam hubungan sosial keluarga, komunitas dan perkumpulan. Perubahan itu ditandai (1) orang tua kehilangan fungsi tradisionalnya dalam melatih anak bekerja dan tidak intensifnya hubungan emosional yang berakibat merosotnya penganutan nilai-nilai moral (etika); (2) peran "orang tua" atau "tokoh" masyarakat dalam hubungan komunitas yang semakin menurun; dan (3) proses differensiasi dan diffusi yang kuat menuju pada pola hubungan sosial masyarakat kota, tetapi disisi lain terdapat semangat "in group feeling" (keprimordialan) sebagai bagian dan upaya mempertahankan nilai-nilai lama.
\end{abstract}

Kata kunci: Hubungan sosial, keluarga, komunitas dan perkumpulan

\section{PENDAHULUAN}

Ketidakseimbangan interaksi dalam satuan masyarakat tertentu selalu menandai terjadinya perubahan sosial. Mengikuti tradisi fungsionalisme struktural (Talcott Par-sons), perubahan sosial menunjuk adanya proses evolusi menuju integrasi masyarakat yang berkeseimbangan. Pola hubungan sosial bergeser melalui proses adaptasi, tetapi keberadaan institusi-institusi sosial, norma-norma dan nilai-nilai sosial-kultural tetap terjaga. Dalam realitasnya, perubahan sosial menunjukkan fenomena-fenomena kon-tradiktif yang berakibat pada keadaan sosial yang labil dan penuh ketegangan yang berkepanjangan dan tidak bertahannya nilai-nilai sosial dan tradisi. Dalam pandangan rnakro, reformasi politik nasional di Indonesia, yang diawali dari pergantian rezim politik orde barn membawa dampak ketidak seimbangan dalam berbagai segi kehidupan. Slogan-slogan kerakyatan dan kebebasan telah melahirkan keberanian warga dalam menuntut hak-hak dan keinginan-keinginan sosial-politiknya yang selama ini tidak diperolehnya. Dad keinginan mendirikan partai politik, otonomi pemerintahan lokal, hingga tuntutan akan pemilikan tanah, pendidikan gratis, dan tuntutan akan santunan-santunan sosial 
Iainnya, tak henti-hentinya berlangsung hingga kini. Pertentangan-per-tentangan timbul sebagai akibat ketidaksiapan menghadapi reformasi, yang melahirkan ketidakseimbangan dan memaknakan belum terintegrasinya bangsa secara menyeluruh. Demikian halnya dalam tinjauan mikro, sebuah satuan masyarakat yang kecil pun tak ubahnya memiliki indikasi-indikasi perubahan yang cenderung sama dengan situasi nasional. Ada-ada saja gejala perubahan yang menarik disimak dalam setiap masyarakat. Perbedaan persepsi dan sikap-sikap kelompok, semakin ditinggalkannya tradisi dan semangat kolektifitas penduduk asli, kecemburuan sosial, hiruk-pikuk dan hilir mudik anggota masyarakat baru, merupakan gejala yang setiap kali mengusik ketenangan hidup penduduk asli masyarakat setempat.

Ada paradoksi dalam hubungan sosial antara kaum pendatang dengan penduduk asli. Sekilas tampak bahwa di kampung Godegan desa Tamantirto terdapat pertambahan jumlah penduduk (urbanisasi) yang signifikan, kemudian teredapat pula pembangunan beberapa infra struktur fasilitas publik, seperti dibuatnya jalan raya baru, hadirnya kampus (UMY). Hadirnya sejurnlah pendatang barn di perkampungan ini tentu akan semakin menambah kompleksitas sosial, akibat dari faktor-faktor, diantaranya (I) penguasaan pengetahuan (tingkat pendidikan), kultur dan tradisi yang dimiliki ma-syarakat (faktor internal) yang saling berbeda, dan (2) desakan eksternal urbanisasi, perkembangan teknologi, ketersediaan fasilitas publik, dan media massa. Faktor-faktor itu membentuk dan merubah format-format kehidupan masyarakat. Lebih jauh kedua faktor itu dapat melahirkan perbedaan paham dan kepentingan. Sementara fenomena memperlihatkan bahwa di kampung ini secara umum kaum pribumi dapat diklasifika-sikan sebagai kelompok yang telah memiliki kemampanan nilai, sehingga progresifitas masyarakatnya didasari persepsi dan keinginan menaecahkan persoalan, membangun cita-cita untuk memperteguh nilai dan tradisi. Di sisi lain terdapat kelompok sosial kelompok pendatang yang cenderung progresif terhadap perubahan. Suasana ini akan mendorong perubahan dan satuan sosial bercirikan agraris, menjadi lebih kompleks. Bangunan pemukiman kaum pendatang yang tak terpisahkan dengan pemukiman pen-duduk asli, disatu sisi mempercepat integrasi, tetapi di sisi bukannya tanpa masalah, tetapi juga kadang melahirkan kecenderungan yang justru mempertajam perbedaan banyak hal.

Pertambahan jumlah penduduk mendorong pertumbuhan infra struktur dan perubahan dalam fungsi-fungsi sosial. Dalam bidang fisik, diperbaikinya jalan-jalan kampung, penerangan jalan, dan didirikannya tempat ibadah (mushalla), dan dibidang sosial nampak semakin semarak. Fenomena berdirinya mushalla dan kegiatan pengajian sampai dengan unculnya kegiatan sosial seperti koperasi dan arisan ibu-ibu dan di kampung ini rupanya membawa format baru dalam hubungan-hubungan sosial, baik dalam hubungan orang tua dengan anak, bahkan lebih luas 
menyangkut hubungan sosial keluarga, komunitas, hubungan perkumpulan masyarakat setempat. Keberadaannya pun sekilas cukup menggiring kaum abangan memasuki wilayah dunia santri. Namun demikian, walaupun pertumbuhan infra struktur dan jumlah penduduk yang terasakan pesat dikampung ini terdapat pula benturan-benturan (diskontinuitas) nilai-nilai dan kepentingan sosial berkenaan hubungan antara penduduk asli dengan pendatang.

Proses adaptasi terhadap nilai-nilai dari kedua kelompok dapat menimbulkan ketegangan sosial. Secara teori, disatu sisi mereka tidak ingin kehilangan nilai-nilai lama dan tradisinya, di sisi lain yakni sebagian anggota masyarakat pendatang memiliki cara berfikir dan nilai-nilai yang berbeda. Fenomena memperlihatkan adanya gejala ketidak sepahaman, dan sikap-sikap kedua masyarakat yang kadang berujung pada lahimya ketegangan sosial. Walaupun perbedaan penganutan nilai/paham dan kepentingan kemudian melahirkan ketegangan seperti itu lazim terjadi pada masyarakat manapun, karena adanya kesenjangan tingkat pendidikan, ekonomi, dan komitmen dalam implementasi nilai dan tradisi, namun hal itu seperti itu selalu pula menjadi persoalan utama dalam proses menuju integrasi sosial.

1. Identifikasi Masalah

Dari uraian latar belakang masalah dapat diidentifikasi adanya beberapa masalah yang dapat diidentifikasi, diantaranya bahwa dalam satuan sosial masyarakat yang dia-mati:

1) Ada fenomena ketidak serasian dalam hubungan sosial terkait kehadiran kaum pendatang.

2) Terdapat perbedaan pandangan/persepsi, dan sikap-sikap, dan kesenjangan antara warga pendatang dengan penduduk asli yang menjadi hambatan dalam proses pembentukan pola hubungan sosial.

3) Adanya gejala diskontinuitas dalam hubungan sosial.

2. Rumusan Masalah

Dari masalah-masalah yang teridentifikasi, rumusan masalah yang diajukan dalam penelitian ini sebagai berikut :

Bagaimana proses perubahan hubungan sosial (keluarga, komunitas dan perkumpulan) pada warga masyarakat Godegan RT 10 Tamantirta ?

3. Maksud dan Tujuan Penelitian

Penelitian ini dapat dikategorikan sebagai jenis penelitian yang memeeahkan problema diskripsi (non eksperimen), yang bennaksud mengungkap proses-proses perubahan pola hubungan sosial. Tujuan yang ingin dicapai penelitian ini adalah mendapatkan infonnasi pengetahuan berupa gambaran umum tentang proses-proses, sebab- 
sebab dan akibat perubahan dalam hubungan sosial (keluarga, komunitas dan perkumpulan).

4. Kegunaan Hasil Penelitian

a. Kegunaan Akademis

Hasil penelitian ini diharapkan dapat memberikan sumbangan pemi-kiran berupa penjelasan teoritis tentang perubahan hubungan sosial dalam kehidupan keluarga, komunitas dan perkumpulan melalui aplikasi teori-teori modernisasi, khususnya teori diferensiasi dan teori difusi sosial.

b. Kegunaan Praktis

Hasil penelitian ini diharapkan dapat memberikan masukan untuk keperluan perencanaan sosial, bark terkait dengan kebijakan-kebijakan pengembangan kawasanterutarna oleh pemerintah lokal, maupunbagi anggota-angota masyarakat lainnya, diantaranya berupa pengenalan karakter masyarakat pedesaan yang tengah mengalami proses perubahan sosial terkait adanya pengaruh-pengaruh faktor internal, seperti perbedaan pandangan dan sikap-sikap sosial yang ada dalam masyarakat dan faktor eksternal berupa fenomena urbanisasi, ketersediaan infra struktur, dan kemajuan teknologi informasi.

5. Kerangka Pemikiran

Analisis terhadap masalah dipecahkan dengan acuan teori modemisasi, khususnya teori differensiasi struktural (Smelser) dan teori diffusi sosial. Teori-teori tersebut merupakan kombinasi antara teori fungsional struktural dan teori-teori evolusi. Teori evolusi menekankan peningkatan proses adaptasi dalam kehidupan sosial atau kebudayaan sebagai subyek perubahan, sedang tradisi fungsionalisme struktural (Talcott Parons) mengutamakan tahapan-tahapan sosiologis, bahwa masyarakat tradisional berubah menjadi modem karena norma, nilai, dan orientasi peranan yang berubah. Teori diferensiasi struktural (Smelser), mengatakan bahwa "differensi adalah suatu suastu dimana sebuah peran atau organisasi pecah menjadi dua peranan atau organisasi atau lebih, yang berfiingsi lebih efektif dalam keadaan histories yang berubah seperti dalam pembagian kerja". (Schoorl dan Venema,1983 :89) Menurutnya, "studi perubahan sosial itu kemudian memusatkan diri pada sebab-sebab differensiasi tersebut, cara-cara terjadinya, dan akibatakibatnya untuk segi-segi lain dan struktural" (1983: 89). Sedangkan teori difusi (Rogers), oleh Schoorl dan Venema (1983:91) dikemukakan, "modernisasi itu terutama adalah proses difusi. Intinya adalah proses dimana individu-individu berganti dari cara hidup yang 
tradisional ke cara hidup yang lebih kornpleks, ke gaya hidup dengan teknologi yang lebih maju yang lebih cepat berubah"

Tradisi dan paradigma teori-teori modernisasi di atas dimaksudkan sebagai perangkat analisis, yang masing-masing akan diperlukan untuk menghadapi obyek persoalannya sendiri-sendiri. Di atas kerangka teori-teori itu, gejala perubahan yang bersifat kompleks atas variabel-variabel yang diteliti itu dijelaskan mengenai proses-proses, sebab-sebab dan akibat-akibatnya. Perubahan pola hubungan sosial itu terkait dengan faktor internal dan faktor ekstemalnya. Analisis dilakukan dengan mengimplikasikan teori-teori di atas, dengan alur pemikiran seperti pada bagan berikut:

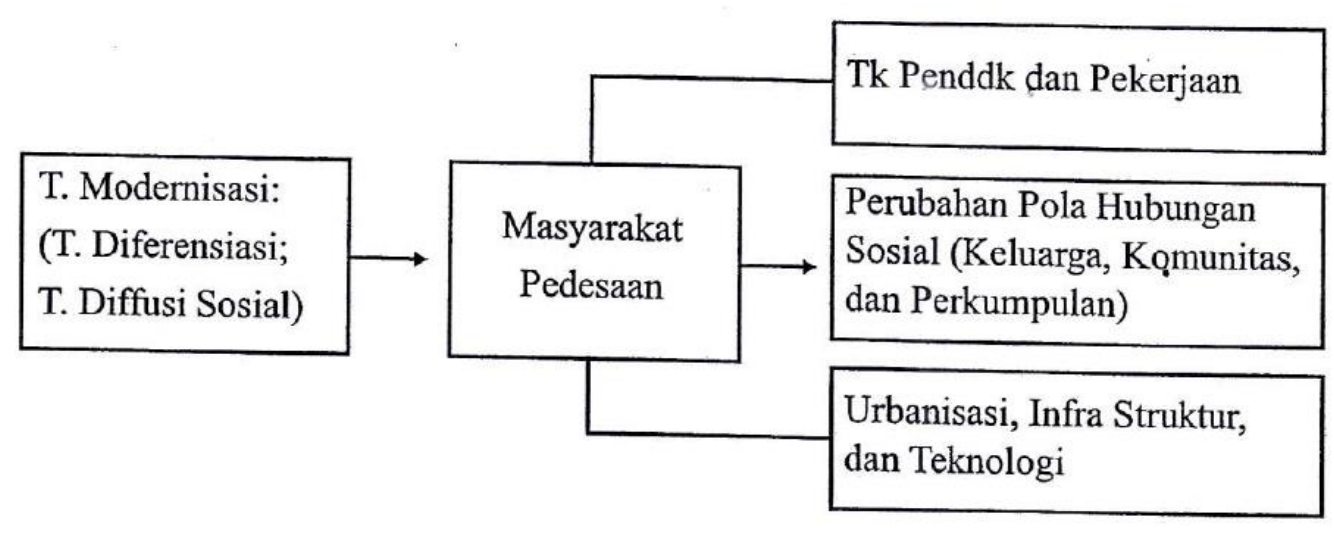

Bagan 1 Alur Pemikiran

\section{METODE PENELITIAN}

Penelitian ini bersifat kualitatif memecahkan problema diskripsi. Analisis bertujuan mendapatkan gambaran umum perubahan pola hubungan sosial. Pola Hubungan Sosial dalam penelitian ini didefinisikan sebagai perubahan pola interaksi atau hubungan sosial, baik hubungan sosial keluarga, hubungan sosial komunitas, dan perkumpulan. Variabel tersebut terinci menjadi sub variable: (1) Perubaban pola hubungan sosial keluarga, mencakup perubahan fungsi keluarga sebagai unit produksi, dan pola hubun-gan orang tua dengan anak; (2) Perubahan pola hubungan komunitas, mencakup kerja sama (kegotong-royongan) dan diskontuniatasnya serta peranan orang tua (tokoh), dan (3) Perubahan pola hubungan sosial perkumpulan atau dalam kegiatan organisasi.

Data yang dihimpun meliputi data primer berupa hasil wawancara dan data sekunder berupa dokumen kependudukan. Data primer diperoleh dengan metode wawancara secara partisipan. Wawancara dilakukan terhadap warga masyarakat RT 10. dengan mengambil waktu atau kesempatan yang tepat, diantaranya pada saat ber-langsungnya kegiatan kebersamaan seperti kegiatan pengerasan jalan, rapat pertemuan warga, dan pada waktu yang longgar peneliti sengaja menemui warga dengan cara yang elegan dan bercanda. Selanjutnya, data sekunder 
diperoleh melalui dokumentasi, dalam hal ini terutama menghubungi pengurus perkumpulan PKK.

Pengolahan data dilakukan dengan menggunakan pendekatan kualitatif yang lazim dalam ilmu sosial, khususnya sosiologi. Gambaran umum (diskripsi) mengenai perubahan pola-pola hubungan sosial diperoleh dengan cara menghubung-hubungkan berbagai gejala, dengan mengikuti cara-cara berfikir logis sesuai acuan teoritis yang ditetapkan dalam kerangka pemikiran.

\section{PEMBAHASAN}

Diskripsi Wilayah Penelitian

Kampung Godegan adalah bagian dari wilayah pemerintahan desa Tamantirta, Kecamatan Kasihan, Kabupaten Bantul. Tepatnya kampong ini merupakan salah satu bagian dari Dusun VII Brajan. Dan segi geografi berada kurang lebih $12 \mathrm{~km}$ arah utara dari kota Bantul, atau sebelah barat kota Yogyakarta, yakni sebelah selatan Jalan Wates Km. 4,5 dipinggiran sungai Bedog. Kampung ini berubah menjadi terbuka, akibat dibangunnya jalan lingkar (ring road) selatan-barat, dibangunnya kampus Baru (UMY), dan diikuti arus urbanisasi.

Kampung Godegan RT 10 terdiri atas 64 Kepala Keluarga (KK), dengan jumlah jiwa 256 orang (Catatan Keluarga Sejahtera RT 10, Oktober 2005). Keadaan warga/penduduk dilihat dari asalnya, terdapat warga/penduduk asli 35 KK (54,69\%) dan 29 KK (45,31\%) pendatang. Angka tersebut memberikan gambaran akan potensi terjadinya perubahan sosial. Wajar bila para pendatang rnemiliki nilai, kebiasaan, atau tradisi yang tidak selalu sama dengan penduduk/ warga asli, sehingga hidup bersama memungkinkan terjadinya difusi atas kultural, atau sebaliknya dapat terjadi disfungsi sosial.

Dilihat dan tingkat pendidikan formalnya, warga/penduduk berijazah SLTA sebanyak 68 orang (26,56\%); SLTP 32 orang (12,50\%); dan SD 40 orang (15,67\%). Sedang yang berijasah Perguruan Tinggi, program diploma dan sarjana muda 7 orang (2,73\%); Sarjana (S1) 21 orang $(8,20 \%)$; dan pasca sarjana (S2) 6 orang $(2,34 \%)$. Kemudian anak-anak yang tengah sekolah di SD 35 orang (13,67\%), sedang warga dewasa tidak memiliki ijazah 47 orang (18,36\%). Data lain menunjukkan, bahwa kelompok masyarakat berpendidikan perguruan tinggi didominasi pendatang, yakni 21 orang S 1 , dan 6 orang S2, sedang kelompok penduduk asli 2 orang berijazah S1, itu pun yang seorang, orang tuanya adalah penduduk asli yang pemah merantau. Dari data di atas menunjukkan besarnya potensi untuk percepatan terjadinya modernisasi, tetapi bukan tidak mungkin melahirkan kesenjangan sosial, antara penduduk/warga ash dan pendatang, 
antara yang berpendidikan tinggi dengan yang lain akibat perbedaan pola berfikir diantara mereka.

Pekerjaan penduduk beragam, dari 180 orang (70,31\%) yang memiliki pekerjaan, terinci: (1) Petani 25 orang (13,69\%), hampir seluruhnya petani persawahan; (2) Wira Usaha Berjualan 17 orang $(9,44 \%)$, adalah warga yang kesehariannya melakukan pekerjaan jual beli makanan kecil, buah-buahan dan sayuran, membuka waning kebutuhan pokok sehari-hari, dan buka kios di pasar, dan wira usaha lainnya, usaha di bidang barang dan jasa, antara lain melayani kebutuhan bahan bangunan berupa pasir dan batu kali, perbengkelan kecil (speda motor/mobil), penjahit, dan pekerjaan lain yang tidak tetap atau mudah berganti sebanyak 12 orang $(6,66 \%)$; (3) Pertukangan (bangunan gedung dan kayu) 8 orang (4,44\%); (4) Pegawai/Karyawan, (swasta dan pegawai negeri sipil) 29 orang $(16,11 \%)$. Dosen perguruan tinggi negeri dan swasta 6 orang $(2,34 \%)$. Beragamnya pekerjaan warga di atas dapat dilihat sebagai sumber/agen perubahan sosial. Kaum intelektual merupakan golongan masyarakat yang cukup potensial. Sebagian besar dan mereka adalah kaum pendatang. Sementara yang lain ialah penduduk/warga asli, yang cenderung menampakkan ciri masyarakat pedesaan yang kuat dalam memegangi tradisi.

1. Perubahan Pola Hubungan Sosial Keluarga, Komunitas, dan Perkumpulan

a. Perubahan Pola Hubungan Sosial Keluarga,

1) Fungsi Keluarga sebagai Unit Produksi

Pembahasan pada sub ini mencakup aspek mata pencaliarian/ pekerjaan dan pemakaian hasil produksi.

a) Mata Pecaharian

Pekerjaan warga beragam, yakni petani (13,89\%), pertukangan $(4,49 \%)$, wira usaha (11,33\%), selebihnya bekerja sebagai pegawai, karyawan, pelayanan/jasa, dan pekerjaan diluar pengolahan tanah. Kelompok masyarakat petani masih menggunakan cara berproduksi dengan pola lama (konvensional). Banyaknya kaum pendatang $(45,31 \%)$ menyebabkan beragamnya jenis pekerjaan. "Warga barn paling awal datang ke sini tahun 1988 ada 1 KK, tahun 1992 ada 2 KK, tahun 1993 tambah $2 \mathrm{KK}$, dan sesudah itu banyak warga baru lain berdatangan" (Sr,16-10-2004). Keberagaman pekerjaan itu mengurangi dominasi ciri agraris (pekerjaan pengolahan tanah) masyarakat.

b) Pemakaian Hasil Produksi

Masyarakat petani menggunakan basil panenan sawah (padi) nya dengan pola tradisional. Masih banyak anggota masyarakat yang rnenggunakan hasil panennya secara langsung untuk memenuhi kebutuhan pangan dalam keluarga sampai musim 
panen perikutnya, tetapi sebagian lainnya menjualnya. "panenan teka sawahku, dak gawa mulih, tak simpen gabah. Kalaning aku butuh beras tak gilingake sak perlune. Kebutuhan beras keluargaku cukup nganti suk aku panen maneh. Berasku ora dak dol". (Sp,23-11-04). Diperoleh pula keterangan yang sama

Aku nggarap sawah acunganteka embokku, kabeh beayapenggarapan aku. Kasile panenan paron, aku separo simbok separo. Gabah dak simpen, nanging nek aku butuh duit kanggo beaya sekolah anakku yo dak dadekke duit. Aku ra nate dodolan beras, kejaba kanggo beaya sekolah anak-anak (Ngt, 19-11-2004)

Diperoleh keterangan pula mengenai perubahan cara penyimpanan basil panen, dulu hasil panen disimpan dalam genthong dengan untingan (untaian padi) dimasukkan ke dalamnya, kini penyimpanan spserti itu masih dilakukan, tetapi padi berupa gabah kering disimpan dalam kantong plastik atau serat.

2) Hubungan timbal balik antara Orang Tua dengan Anak

Ada perbedaan suasana alam kehidupan masyarakat pedesaan generasi terdahulu dibanding generasi yang sekarang. Kebiasaan dan tradisi para orang tua masa lalu selalu tak terpisahkan/didampingi anak-anaknya, tetapi kini suasana seperti itu berubah karena zaman berbeda, sehingg orang tua merasakan ada sesuatu yang hilang.

Orang tua bekerja di sawah sendirian. Anak-anak sama sekali tak mau membantu pekerjaan di sawah. Berbeda dengan sewaktu kecil saya dulu, ikut kerja keras membantu orang tua. Saya selalu bangun jam tiga pagi terus mengantar orang tua berjualan ke pasar, sesudah itu 'ngangsu air' dari sumur tetangga yang agak jauh karena dulu hanya ada satu di sekitar sini, barn kemudian berangkat sekolah (Ngt., 8-7-05).

Pernyataan yang sama juga dikemukakan oleh seorang responden, anak-anak dulu mudah di ajak kerja ke sawah, kebun atau yang lain. Berbeda dengan anak-anak zaman sekarang. Masa kecil saya, saya setiap hari diwajibkan orang tua untuk melakukan tiga hal: (1) 'nyapu' (yakni menyapu lantai dan halaman rumah); (2) 'nggodog wedang' (merebus air, yakni untuk menuman); (3) 'ngresiki lethong sapi' (membersihkan kotoran sapi, yakni di kandang sapi). Biasanya 'jangan' (sayur) sudah dimasak simbok (si ibu) kemarin sore, sehingga pagi tinggal menghangatkan. Begitu hampir setiap hari. Anak cucu saya sekarang suruh `nyapu' lantai jubin rumah sulitnya bukan main. Tetapi cucu-cucu saya di sekolah nilai raportnya selalu bagus (Skd.,10-07-05).

Orang tua merasakan adanya sesuatu yang hilang, yakni fungsi ayah dalam melatih bekerja anak, dan fungsi ibu dalam mengembangkan emosi anak. Akibat akan mambawa pengaruh, yakni anak menjadi terlambat atau bahkan tak pemah mengerti 
akan semangat, kiat, dan hakekat bekerja, yang dimiliki orang tuanya, di samping orang tua tak lagi memiliki momen untuk melestarikan seperangkat nilai-nilai, dan tradisi dalam perjuangan hidupnya. Dilihat dari teori differensiasi struktural, hilangnya fungsifungsi itu, menjadikan para orang tua percaya sepenuhnya pada pendidikan sekolah atas anaknya, walaupun mereka tak cukup paham persoalan substansi pendidikan yang diajarkan di sekolah. Kini, orang tua sendirian bekerja keras di sawah dan ladangnya, anak-anak sibuk dengan hitungan-hitungan matematika dan diskusinya di sekolah. Konsekuensi lain, para orang tua terbebani beaya sekolah, dan beaya-beaya anak lainnya. "Anak-anak sekarang naik speda sudah tidak mau lagi, apa lagi kalau bukan tambahan beaya, bis kotalah, sangu, dll. ..." (Skd., 10-7-05).

Dalam hal perkawinan, peran orang tua tak lagi dominan dalam menentukan calon pasangan anaknya. "Saya dulu kawin dijodohkan orang tua, zaman sekarang lain. Saya memberikan kebebasan kepada anak saya untuk menentukan sendiri pilihan pasangannya nanti" (K.Kh., 08-07-2004). Mengenai hal ini, berapa responden mengaku sama, sehinga bisa diartikan adanya peran orang ma yang telah bergeser dalam hal perkawinan anaknya.

b. Perubahan Pola Hubungan Sosial dalam Komunitas

Perubahan pola hubungan sosial dalam komunitas dapat dilihat da-lam hal kegiatan kebersamaan dan peran orang tua dalam komunitas.

1) Kebersamaan dalam Komunitas

Ciri kebersamaan atau kolektifitas dapat ditemukan dalam beberapa peranannya (sesepuh). Sementara itu undangan sedate tersebar, tetapi yang punya rumah untuk ditempati baru diberi tahu kemudian. "Ternyata beliau diberi pemberitahuan bahwa rumahnya akan ditempati untuk rapat, setelah undangan rapat diedarkan lebih dulu" (Nn, 16-09-05), menunjukkan adanya kesan bahwa legitimasi atas orang yang dituakan dalam komunitas ini sangat diperlukan; (2) Pada pembentukan panitia pembangunan jalan kampungterdapat peranan orang tua yang sangat kuat. "Pembentukan panitia pengerasan jalan dilakukan dengan cara ditunjuk oleh beberapa orang yang dituakan dikampung ini, tidak melalui forum rapat Rebo Wage bersama warga seperti lazimnya. (Psd, 14-04-04). Disisi lain, pernyataan di atas dapat dimaknakan sebuah kritik terhadap peranan orang tua yang mengesampingkan forum rapat. 
3) Perubahan Pola Hubungan dalam Perkumpulan/Organisasi

Terdapat sejumlah perkumpulan dalam masyarakat yang diteliti, dengan karakteristiknya masing-masing. Diantaranya, Forum Pertemuan warga RT 10 (Rebo Wage), Kelompok Perondan,PembinaanKesejahteraan Keluarga (PKK), Persatuan Pemuda/Pernudi Rukun Kampung (PPRK), Kelompok Sido Klakon yang bergerak pada penyediaan tenda dan fasilitas untuk pertemuan/hajatan, Kelompok tahlilan Ngudi Rahayu, dan Organisasi Ketakmiran Mushalla Al Amin, yang kesemuanya merupakan organisasi yang formal, sehingga seperti lazimnya memiliki struktur kepengurusan.

Dilihat aktivitasnya, sebagian menampakkan ciri kelompok/organisasi yang masih lekat dengan cirri ketradisionalan, sebagian lainnya cenderung memperlihatkan ciri kekotaannya. Dalam hal yang pertama, terlihat adanya hubungan sosial yang bersifat dotninasi, sehingga tidak jarang berakibat terjadinya ketegangan. Fenomena hubungan internal yang intensif (in group relationship) sering menampak, polanya mengikuti konsep hubungan keprimordialan. Biasanya diawali dari perbedaan pandangan/kepentingan. Selanjutnya semangat kolektifitas (sempit) muncul dengan suatu ungkapan perasaan yang bernuansakan keberpihakan. Kuatnya ikatan sering menampak ketika perselisihan paham/kepentingan tengah berlang-sung. Tetapi bentuk hubungan yang demikian berakhir ketika perpedaan itu terselesaikan, walau perlu waktu untuk bersesuaian. Dalam hal kedua, hubungan sosial yang lebih elegan yang didasarkan pada prinsip equality dan rasionalitas, yang relatif lebih bersifat kekotaan terdapat pada organisasi PICK danKetalcmiran Mushalla. Dalam kenyataannya, organisasi-organisasi ini dikendalikan oleh warga yang cukup memiliki pengalaman berorganisasi secara modern. Sifat itu ditanadai dengan dimilikinya mekanisme kerja kepengurusan dan perencanaan program kerja yang sistematis, serta sistem administrasi termasuk pelaporan keuangan yang bisa diper-tanggung-jawabkan secara obyektif. Namun demikian, kemajuan organisasi ini juga bukannya terbebas dan pengaruh ketradisionalan, karena anggota-anggotanya juga warga masyarakat yang sama.

\section{KESIMPULAN}

Perubahan Pola Hubungan Sosial dalam Keluarga

a. Perubahan fungsi keluarga sebagai unit produksi:

1) Para petani masih menggunakan cara-cara produksi pengolahan tanah dengan pola konvensional, perubahan terjadi hanya pada jumlah populasinya yang semakin berkurang karena berganti pekerjaan. Hadirnya kaum pendatang menambah 
keberagaman jenis pekerjaan sehinga mengurangi ciri kehidupan masyarakat yang agraris.

2) Hasil produksi pertanian oleh sebagian anggota masyarakat menyimpan hasil panennya, dan hanya digunakan untuk memenuhi kebutuhan pokok keluarga sampai dengan masa panen berikutnya (agraris), sebagian lainnya tak lagi demikian, melainkan dijual.

b. Perubahan pola hubungan antara orang tua dengan anak, terutama hilangnya fungsi ayah dalam melatih kecakapan kerja anak dan berkurangnya fungsi lbu dalam menanamkan kasih sayang dan pendidikan etika pada anak, karena komunikasi antara orang tua dengan anak kurang intesif. Dalam hal pelatihan kecakapan kerja anak, orang tua cenderung percaya sepenuhnya kepada sekolah.

c. Perubahan Pola Hubungan Sosial Komunitas

a. Pada nmasyarakat yang diteliti, kegotong-royongan masih kuat, walau di sisi lain terdapat pandangan-pandangan dan sikap-sikap yang kritis dengan argumentasi yang variatif tingkat rasionalitasnya.

b. Peran sosial orang tua menandai sebagian besar aktivitas kebersamaan, tetapi di sisi lain terdapat indikasi berkurang atau semakin sempitnya peranan itu.

d. Perubahan Pola Hubungan Sosial Perkumpulan

a. Terdapat beberapa macam perkumpulan yang pengelolaannya sebagian bersifat tradisional (bercirikan kekerabatan), sebagian lainnya menggunakan prinsip-prinsip organisasi modern.

b. Banyaknya perkumpulan mengindikasikan adanya interaksi dais keter-ikatan warga dengan perkumpulan atau organisasi. Afiliasi-afiliasinya membawa konsekuensi. Disatu sisi memperkuat ciri-ciri atau nilai-nilai ketradisionalan, sehingga gejala disfungsi sosial yang timbul dapat dilihat sebagai gejala "in group belonging" yang menguat, tetapi di sisi lain berkembang ciri masyarakat kekotaan.

\section{DAFTAR KEPUSTAKAAN}

Chirist Daniel. 1986. Social Changes in Modren Era. Hacourt Brace Jovanivich Inc. Geertz Clifford. 1973. The interpretation of Cultures. London: Hutchonsin

Harrison David. 1991. The Sociology of Modernization and Development. London: Routledge. Leibo Jefta (Ed.). 1986. Sosiologi Pedesaan. Yogyakarta: Andi Ofset.

Moleong Lexi J. 2006. Metodologi Penelitian Kualitatif. Bandung: PT Remaja Rosdakarya. 
Sayogyo dan Sayogya Pujiwati (Ed.). 1986. Sosiologi Pedesaan. Yogyakarta: Gadjah Mada Press.

Sumardjan Sela. 1962. Social Change in Yogyakarta. New York: Cornel University Press.

Susanto S. Astrid. 1983. Pengantar Sosiologi dan Perubahan Sosial. Pcnertbit Bina Cipta.

Weiner Myron. TT. Modernisasi: Dinamika Pertumbuhan. Voice of America Forum Lectures. 